\title{
Why do closed-end funds repurchase stock?
}

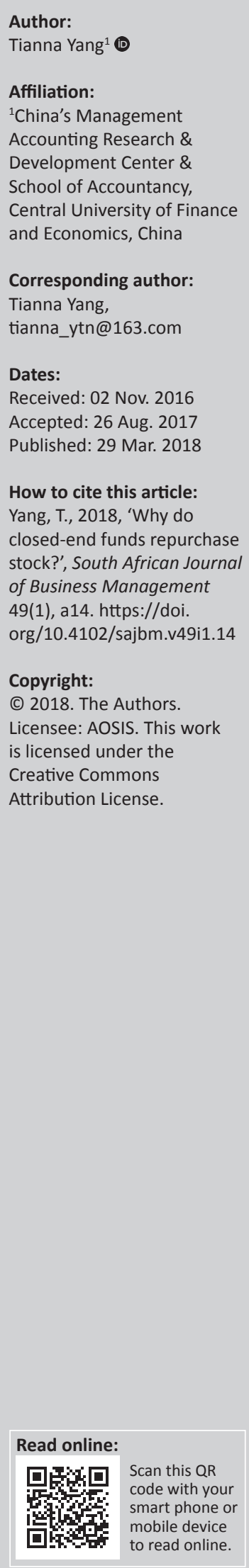

With special institutional characteristics and regulatory requirements, what factors can motivate UK closed-end funds to engage in open-market repurchases? Investigating repurchase transactions on a financial-year basis, it was found that funds repurchase shares to reduce discounts and to increase the net asset value per share, as directors claim, but not to increase fund liquidity. It was also found that funds repurchase shares to increase leverage ratios. Unlike conventional firms, neither distributing excess cash nor substituting dividend payouts promotes fund repurchases. Fund size has a negative effect on repurchase decision.

\section{Introduction}

There is substantial literature on conventional firms' repurchase activities (see Barth \& Kasznik 1999; Bartov 1991; Brav et al. 2005; Grullon \& Michaely 2004; Jagannathan \& Stephens 2003; Kahle 2002; Lie 2005; Netter \& Mitchell 1989; Nohel \& Tarhan 1998; Padgett \& Wang 2007; Rau \& Vermaelen 2002), while studies on closed-end fund repurchases are rare. However, according to Morningstar, by the end of June 2010, more than 2700 closed-end funds had been listed on the major stock exchanges of different countries around the world, raising approximately $\$ 806$ billion. Despite the importance of closed-end funds as an asset class in the global market, they remain underresearched. The topic of closed-end fund repurchases has received little attention in part because of limited disclosure of repurchases (in the USA) and also the neglected agency effect of repurchases, which is unique to closed-end funds. In this paper, I explore whether and why closed-end funds repurchase their own shares in a market with comprehensive disclosure of repurchase transactions (the UK). To my knowledge, this is the first paper to explore the determinants of the decision to engage in open-market repurchase transactions rather than the effects of repurchase intention announcements, in the case of the closed-end fund industry.

I selected UK closed-end funds to conduct the analysis mainly for two reasons. Firstly, all UK closed-end funds are listed on the London Stock Exchange's Main Market, making it the largest, most diversified and most actively traded closed-end fund industry in the world. Secondly, and most importantly, it is compulsory for UK funds to disclose the actual price and volume of every repurchase within 1 day of the transaction. In the USA, in contrast, closed-end funds are not required to disclose details for each transaction. Although since 2004 the USA requires quarterly disclosure on share repurchases, US firms including closed-end funds are only required to disclose the average repurchase price and average repurchase volume, rather than the exact information for each individual repurchase transaction. As a consequence, US repurchase studies only use estimated repurchase transactions or repurchase intention announcements. However, many firms do not actually repurchase shares after announcing their intentions (see Lie 2005; Singh, Zaman \& Krishnamurti 1994; Stephens \& Weisbach 1998). As a result, studies using intention announcements can make measurement errors and may provide misleading results. Research into UK closed-end funds, on the other hand, benefits from more accurate repurchase execution data.

Most of the existing repurchase motivation literature studies conventional firms. Many researchers believe that insiders repurchase shares to signal undervaluation and their confidence about future operational performance (see Bartov 1991; Comment \& Jarrell 1991; Dittmar 2000; Liu \& Ziebart 1997; Netter \& Mitchell 1989; Oswald \& Young 2004; Vermaelen 1981). Others favour the free cash flow hypothesis, which states that a firm repurchases shares to distribute excess cash in the absence of investment opportunities and to increase firm value (see Dittmar 2000; Grullon \& Michaely 2004; Jagannathan \& Stephens 2003; Jensen 1986; Lie 2005; Padgett \& Wang 2007; Wang et al. 2009). Firms may repurchase shares as a substitute for dividend payouts (see Allen, Bernardo \& Welch 2000; Fenn \& Liang 2001; Jolls 1998). As stated by Opler and Titman (1994), Dittmar (2000) and Hovakimian, Opler and Titman (2001), firms may repurchase shares in order to increase their leverage ratio and thus achieve a target capital structure. 
Closed-end funds are listed investment companies, and their corporate structure is different from that of conventional firms. Closed-end funds normally trade at discounts of the underlying net asset value (NAV). Because of their unique characteristics, funds' repurchases are expected to be motivated by different objectives than those of conventional firms. Typically, agency theory implies, according to An, Gemmill and Thomas (2012), that fund directors may use the weapon of repurchases (reducing fund size and the future stream of management fees) to penalise managers for poor performance (reflected by a wide discount as indicated by Gemmill \& Thomas 2006) and so align the interests of managers and shareholders and mitigate the agency problem. On the other hand, if the discount becomes severe, the fund manager may elect to repurchase shares to avoid arbitrageurs from taking over the fund and reorganising it or voting out the manager. Furthermore, closed-end funds repurchase shares at a discount compared to the NAV, which is transparently profitable and can increase the NAV per share for the remaining shareholders. Also, it is argued that repurchases may increase the liquidity of the fund and increase the share price (see Akhigbe, Kim \& Madura 2007; Pontiff 1995; Porter, Roenfeldt \& Sicherman 1999). According to these theories, reducing the discount, increasing the NAV per share and raising liquidity are all predicted to motivate closed-end funds' repurchase activities.

These objectives are frequently expressed by fund directors in their annual reports prior to requesting authorisation for a repurchase programme from the annual general meeting of shareholders (see AIC 2010). The hand-collected repurchase motivations given by the directors of UK-domiciled closedend funds executing repurchases during the period 1999-2009 are summarised in Table 1. As shown in Panel A, there are eight categories of declared motives. In Panel B it can be seen that more than $50 \%$ of the repurchase funds gave multiple repurchase motives in their annual reports. I counted the frequency with which each of the main objectives was mentioned. 'To enhance net asset value per share' and 'to reduce discount' were the most frequently espoused reasons, together making up almost $60 \%$ of the 130 observations. Another explicit statement is 'to provide liquidity for shareholders', but this made up only $4.62 \%$ of the sample. In contrast, the other categories are vague claims that may have various interpretations. In this paper, I conduct an in-depth analysis of the three explicitly declared motives, based on the effects of the discount, the NAV return and liquidity on fund repurchase decisions.

In addition to the three declared fund repurchase motivations discussed above, the institutional intricacies and regulation requirements of closed-end funds may cause some of the standard repurchase motivations of conventional firms to be reformed in various ways for the funds. Specifically, the share prices of closed-end funds have been shown to move upwards after repurchase announcements (e.g. Akhigbe et al. 2007; An et al. 2012; Porter et al. 1999). To uphold shareholders' interests, if a fund's share price performance remains unsatisfactory,
TABLE 1: Declared motives for open market repurchases of closed-end funds. Panel A: Categories of declared motives

\begin{tabular}{lcc}
\hline $\begin{array}{l}\text { The closed-end fund launches the repurchase } \\
\text { programme: }\end{array}$ & Observations & Proportion (\%) \\
\hline $\begin{array}{l}\text { 1. To enhance net asset value per share for } \\
\text { remaining shareholders }\end{array}$ & 38 & 29.23 \\
$\begin{array}{l}\text { 2. To reduce the level of price discount to net } \\
\text { asset value }\end{array}$ & 38 & 29.23 \\
$\begin{array}{l}\text { 3. To maximise interests of shareholders } \\
\begin{array}{l}\text { 4. To increase the flexibility of share capital } \\
\text { management }\end{array}\end{array}$ & 24 & 18.46 \\
$\begin{array}{l}\text { 5. To correct any imbalance between supply and } \\
\text { demand of ordinary shares }\end{array}$ & 9 & 9.23 \\
$\begin{array}{l}\text { 6. To provide liquidity for shareholders wishing to } \\
\text { sell their ordinary shares }\end{array}$ & 6 & 6.92 \\
$\begin{array}{l}\text { 7. To be a useful means of accelerating capital } \\
\text { return to shareholders }\end{array}$ & 2 & 4.62 \\
$\begin{array}{l}\text { 8. To be a valuable tool to have at its disposal } \\
\text { Total }\end{array}$ & 1 & 1.54 \\
Panel B: Motives distribution among closed-end funds with repurchase transactions \\
Funds do not declare any motive & 12 & 15.79 \\
Funds declare one motive & 25 & 32.89 \\
Funds declare two motives & 22 & 28.95 \\
Funds declare three motives & 7 & 9.21 \\
Funds declare four motives & 10 & 13.16 \\
Total & 76 & 100 \\
\hline
\end{tabular}

Tota 100

Notes: My paper investigates the motives for repurchase executions. I manually collected declared motives by funds' directors from the 'Share Buy-back' section of annual reports for the 76 repurchase funds. In Panel A, the first column describes the eight categories of declared motives and orders them based on their frequency. The second column shows number of observations justified for each category and the third column calculates the proportion of each category out of the total 130 observations. In Panel B, the first column categorises the 76 repurchase funds by the number of motive types in Panel A from declaring no motive to declaring four multiple motives. The second column displays fund numbers for each of the five categories and the third column is the proportion for this distribution.

directors may use the threat of executing repurchases to discipline the fund manager. As a consequence, an erosion in price returns may motivate share repurchases for closed-end funds in a similar way to the case of conventional firms. In contrast to the case of conventional firms, fund size is expected to have a negative effect on repurchases, because of its negative relationship with the fund discount (see Gemmill \& Thomas 2002). Moreover, the free cash flow theory is not expected to apply to UK closed-end funds because they are not allowed to hold cash in excess of current investment opportunities and they are normally fully invested. Dimson and Minio-Paluello (2002) pointed out that closed-end funds domiciled in the UK are required to distribute at least $85 \%$ of their annual income in the revenue reserves to shareholders as dividends. Also, UK funds are precluded from distributing dividends from the capital reserves, which are normally used to finance fund repurchases. Consequently, UK fund repurchases are not expected to be used as a substitute for dividend payouts. As stated by An et al. (2012), closed-end funds have a special tax status that makes interest not deductible. Although a closed-end fund cannot benefit from the tax shield by deducting debt interest, the fund's leverage can boost the NAV return (i.e. magnify the investment performance). However, the majority of funds operate with low levels of leverage. Accordingly, low leverage ratios may motivate closed-end fund repurchases.

This paper investigates each of these predictions derived from the institutional characteristics of closed-end funds, to determine the unique set of repurchase objectives for the closed-end fund industry and how these motives interrelate. 
In comparison, the existing repurchase literature on closedend funds focuses solely on changes in fund performance after repurchase intention announcements, rather than examining the factors that affect the decision to execute a repurchase. In this way, this study differs from the existing literature and reveals determinants of repurchases that might otherwise remain hidden. Further, the test of the impacts of the discount, the NAV return and liquidity on the decision to execute a repurchase provides an alternative means to examine the plausibility of the three theories described by An et al. (2012).

The original contributions of this study are as follows. With a sample of 711 fund-year observations, I found a positive impact of discount on repurchase volume was found (as a fraction of outstanding shares) and repurchase probability, suggesting that closed-end funds repurchase shares to reduce discounts. Further, I found a negative relation between NAV return and both repurchase volume and probability, indicating that funds use buy-backs to increase the NAV per share. These findings are consistent with the motives declared by funds prior to repurchases and also confirm the agency theory and repurchase-profits theory propounded by An et al. (2012) and the takeover avoidance theory suggested by Barclay, Holderness and Pontiff (1993). In contrast, I found no evidence in support of funds' stated objective of using buy-backs to increase liquidity. Price return was not found to significantly affect fund repurchases either. As anticipated, contrary to the case of conventional firms, fund size has a negative effect on both the repurchase volume and probability for these funds. Neither distributing excess cash nor replacing dividends appears to be a motivation for closed-end funds' share repurchases. In spite of this, the leverage ratio was found to have a significantly negative effect on fund repurchase decisions. This result has substantial economic significance.

The rest of the article is structured as follows. The 'Data and methodology' section describes the data and methodology. The 'Results' section reports the results of the study and, finally, the 'Conclusions' section concludes the article.

\section{Data and methodology}

Initially, I identified a population of 315 closed-end funds that launched IPOs on the London Stock Exchange between April 1998 and May 2009. Split-capital closed-end funds issue more than one class of shares and have a complex and special capital structure that is likely to make their repurchase motivations different to those of conventional closed-end funds that issue only one class of ordinary share. Also, the repurchase motive predictions developed in this study are not appropriate for offshore closed-end funds because they must comply with different tax and corporation requirements from those of closed-end funds domiciled in the UK. As a result, I excluded 99 split-capital and 97 offshore closedend funds from the population, retaining a sample of 119 conventional closed-end funds domiciled in the UK for the investigation. Based on the UK repurchase disclosure regulations, I collected actual repurchase announcements,
TABLE 2: Data and sample selection.

Panel A: Closed-end funds sample selection

A population of IPOs from April 1998 to May 2009 Observations

Less: Split closed-end funds

Less: Offshore closed-end funds

The population of conventional closed-end funds domiciled in the UK

Final sample of UK-domiciled closed-end funds

Repurchase closed-end funds

Non-repurchase closed-end funds

41

Panel B: Manually collected execution announcements for the 76 repurchase closed-end funds

Original number of daily repurchase transactions

Total number of daily repurchase transactions

Notes: Panel A describes the process of fund selection from the population of 315 closedend fund IPOs to the final 117 UK-domiciled closed-end funds, in which 76 made repurchases while 41 funds did not. Panel B shows the number of repurchase execution announcements manually collected from both the InvestEgate website and the Factiva database for the 76 repurchase funds, as well as the number of repurchase fund-years based on the 3221 repurchase transaction announcements.

rather than intention announcements, from the Morningstar fund database for each of these funds. For the period between the IPO dates of each fund and December 2009, I identified that 76 closed-end funds executed at least one open-market repurchase transaction, 41 funds did not make any openmarket repurchases and two funds did not provide any information. Finally, I manually collected 3229 ordinary shares' open-market repurchase execution announcements for the above-mentioned 76 conventional closed-end funds. The information I collected about each announcement included an announcement date, an execution date, a repurchase price, the number of repurchased shares and whether the repurchased shares were cancelled or held as treasury shares. For funds that executed more than one transaction on the same day, I aggregated their repurchases. This gave a final sample of 3221 repurchase execution announcements. Moreover, these execution announcements can be aggregated into 207 repurchase fund-year observations, covering the financial years 1999-2009. Table 2 provides a breakdown of the sample selection process.

\section{Fund-year repurchase analysis}

To match the 207 repurchase fund-years, I established a subsample of 544 non-repurchase fund-years between the financial years 1999 and 2009. The non-repurchase subsample comprised both funds that made no repurchases over the entire sample period and repurchase funds that made no repurchases within a given year. Starting from 751 fund-year observations, I excluded 7 observations without annual reports for the financial year preceding the repurchase and 33 observations having missing data. The final sample comprised 711 fund-year observations, including 207 fundyears during which at least one repurchase transaction took place (so-called repurchase fund-years), and 504 fund-years without a repurchase transaction.

Dittmar (2000), Lee, Hsieh and Peng (2005) and Oswald and Young (2008) used either the Logit or the Tobit model to examine repurchase motives. These models can handle 
the censored observations, which are non-repurchase observations that occur throughout the investigation period, and consequently provide consistent estimates. I applied both the Tobit and Logit models as follows:

$$
\begin{aligned}
\text { Repurchasefraction }_{i t}= & \alpha_{i t}+\beta_{1} \text { Discount }_{i(t-1)}+\beta_{2} \text { NAVreturn }_{i(t-1)} \\
& +\beta_{3} \text { Spread }_{i(t-1)} / \beta_{3} \text { Volume }_{i(t-1)} \\
& +\beta_{4} \text { Pricereturn }_{i(t-1)}+\beta_{5} \text { Lnasset }_{i(t-1)} \\
& +\beta_{6} \text { Cash }_{i(t-1)}+\beta_{7} \text { Cashflow }_{i(t-1)} \\
& +\beta_{8} \text { Leverage }_{i(t-1)}+\beta_{9} \text { Dividendpayout }_{i(t-1)} \\
& +\beta_{10} \text { Sectordummies }_{i t} \\
& +\beta_{11} \text { Yeardummies }_{i t}+\varepsilon_{i t} \\
\text { Repurchasedummy }_{i t}= & \alpha_{i t}+\beta_{1} \text { Discount }_{i(t-1)}+\beta_{2} \text { NAVreturn }_{i(t-1)} \\
& +\beta_{3} \text { Spread }_{i(t-1)} / \beta_{3} \text { Volume }_{i(t-1)} \\
& +\beta_{4} \text { Pricereturn }_{i(t-1)}+\beta_{5} \text { Lnasset }_{i(t-1)} \\
& +\beta_{6} \text { Cash }_{i(t-1)}+\beta_{7} \text { Cashflow }_{i(t-1)} \\
& +\beta_{8} \text { Leverage }_{i(t-1)}+\beta_{9} \text { Dividendpayout }_{i(t-1)} \\
& +\beta_{10} \text { Sectordummies }_{i t} \\
& +\beta_{11} \text { Yeardummies }_{i t}+\varepsilon_{i t}
\end{aligned}
$$

where $i$ represents the fund and $t$ is the financial year-end of the fund. The dependent variable in the Tobit model (Eqn 1) is the repurchase fraction, which is equal to the number of repurchased shares as a percentage of the total number of outstanding shares at the previous year-end. The dependent variable in the Logit model (Eqn 2) is a binary variable taking a value of 1 for fund-years with repurchases and 0 otherwise. Table 3 provides definitions of the variables used in the fund-year repurchase analysis.

\section{Empirical findings \\ Summary statistics for repurchase transactions}

Table 4 provides summary statistics for the collected repurchase transactions. Panels A and B show the distribution of the fund repurchase value and percentage, respectively,

\begin{tabular}{|c|c|c|}
\hline Variable & Definition of variable & Data source \\
\hline \multicolumn{3}{|c|}{ Dependent variables } \\
\hline $\begin{array}{l}\text { Repurchase } \\
\text { fraction }\end{array}$ & $\begin{array}{l}\text { Repurchased number of shares in fiscal year } t \\
\text { divided by outstanding shares at the end of } \\
\text { year } t-1 \text { and set to } 0 \text { for non-repurchase } \\
\text { fund-years; in } \% \text {. }\end{array}$ & $\begin{array}{l}\text { Repurchase } \\
\text { announcements, } \\
\text { Datastream and } \\
\text { annual reports }\end{array}$ \\
\hline $\begin{array}{l}\text { Repurchase } \\
\text { dummy }\end{array}$ & $\begin{array}{l}\text { Equal to } 1 \text { (or } 0 \text { ) if a fund did (or did not) } \\
\text { repurchase in fiscal year } t .\end{array}$ & $\begin{array}{l}\text { Repurchase } \\
\text { announcements }\end{array}$ \\
\hline \multicolumn{3}{|c|}{ Independent variables } \\
\hline Discount & $\begin{array}{l}\text { Difference between net asset value and share } \\
\text { price divided by net asset value; in \%. Discount } \\
\text { at the prior fiscal year-end is used. }\end{array}$ & Datastream \\
\hline NAVreturn & $\begin{array}{l}\text { Difference between net asset value return } \\
\text { index and this index on prior trading day } \\
\text { divided by prior day's index; in \%. NAV return } \\
\text { at the prior fiscal year-end is used. }\end{array}$ & Datastream \\
\hline Spread & $\begin{array}{l}\text { Difference between ask and bid prices divided } \\
\text { by average of the two prices; in } \% \text {. Spread at } \\
\text { the prior fiscal year-end is used. }\end{array}$ & Datastream \\
\hline Volume & $\begin{array}{l}\text { The ratio of number of shares traded on the } \\
\text { market to total number of outstanding shares; } \\
\text { in } \% \text {. Trading volume at the prior fiscal } \\
\text { year-end is used. }\end{array}$ & Datastream \\
\hline Pricereturn & $\begin{array}{l}\text { Difference between current price return index } \\
\text { and return index on prior trading day divided } \\
\text { by prior day's return index; in \%. Return at the } \\
\text { prior fiscal year-end is used. }\end{array}$ & Datastream \\
\hline Lnasset & $\begin{array}{l}\text { Natural logarithm of total assets at the prior } \\
\text { fiscal year-end. }\end{array}$ & $\begin{array}{l}\text { Datastream and } \\
\text { annual reports }\end{array}$ \\
\hline Cash & $\begin{array}{l}\text { The ratio of cash and equivalents to total assets } \\
\text { at the end of prior fiscal year; in } \% .\end{array}$ & $\begin{array}{l}\text { Datastream and } \\
\text { annual reports }\end{array}$ \\
\hline Cashflow & $\begin{array}{l}\text { Cash flow from operation: the ratio of the sum } \\
\text { of net income and all non-cash charges or } \\
\text { credits to total assets at the end of prior fiscal } \\
\text { year; in \%. }\end{array}$ & $\begin{array}{l}\text { Datastream and } \\
\text { annual reports }\end{array}$ \\
\hline Leverage & $\begin{array}{l}\text { Debt-to-asset ratio at the prior fiscal year-end; } \\
\text { in } \% \text {. }\end{array}$ & $\begin{array}{l}\text { Datastream and } \\
\text { annual reports }\end{array}$ \\
\hline Payout & $\begin{array}{l}\text { Ratio of dividends per share to earnings per } \\
\text { share at prior fiscal year-end; in \%. }\end{array}$ & $\begin{array}{l}\text { Datastream and } \\
\text { annual reports }\end{array}$ \\
\hline
\end{tabular}
for each financial year. During the whole sample period, there were a total of 207 fund-years with repurchases, with an aggregate repurchase value of $£ 794.773 \mathrm{~m}$ and a mean (median) value of $£ 3.794 \mathrm{~m}(£ 1.45 \mathrm{~m})$.

Column 2 in both Panels A and B shows the number of funds with at least one repurchase transaction in a given year. The number of repurchasing funds more than doubled between the financial years 1999 and 2000 and continuously stayed at that level after 2000. This may be because of changes in the UK tax regulations and the Companies Act in the year 1999 that removed the two obstacles to repurchase activity. In contrast, the change in regulations (effective from 1 December
TABLE 3: Definitions of all variables.

2003) removing the requirement for repurchased shares to be cancelled and allowing them to be held as treasury stocks seems to have had no positive impact on the value of repurchases, which actually fell in 2004. The repurchase value soared from 2000 to 2001 and there was another dramatic increase from 2005 to 2006. From Panel A, it can be seen that in the sample period the repurchase value peaked in 2007 at a total of $£ 202.21 \mathrm{~m}$, more than 22 times the value in the year 1999. However, these increases are not statistically significant for either the mean or median values.

Under current listing rules in London, the maximum open-market repurchase for a UK closed-end fund in any financial year is $15 \%$ of the total outstanding shares. As seen in Panel B, in every year except 1999 and 2002, the maximum repurchase percentage almost reached the upper limit. The mean and median values of the repurchase percentage shown in Panel B follow a similar pattern to that of the repurchase value shown in Panel A. The main difference is that the year 2006 rather than 2007 saw the largest repurchase percentage across the whole sample period. The mean (median) value for the year 2006 was 8.207 (6.141\%). Overall across the 207 fund-years, shares were bought back at a mean (median) ratio to outstanding shares of 4.525 $(3.182 \%)$. 
Table 4: Summary of statistics for share repurchases of UK closed-end funds.

\begin{tabular}{|c|c|c|c|c|c|c|c|c|c|}
\hline \multicolumn{10}{|c|}{ Panel A: Value of share repurchases ( $\mathrm{f}$ million) } \\
\hline Fiscal year & Number of funds & Mean & SD & Maximum & Q3 & Median & Q1 & Minimum & Sum \\
\hline 1999 & 6 & 1.523 & 1.799 & 5.000 & 1.730 & 0.985 & 0.252 & 0.185 & 9.137 \\
\hline 2000 & 13 & 2.153 & 1.631 & 5.160 & 3.150 & 2.460 & 0.811 & 0.130 & 27.991 \\
\hline 2001 & 13 & 4.170 & 6.579 & 25.500 & 3.610 & 2.520 & 1.370 & 0.375 & 54.206 \\
\hline 2002 & 15 & 1.365 & 2.181 & 8.730 & 1.570 & 0.688 & 0.143 & 0.006 & 20.475 \\
\hline 2003 & 18 & 2.402 & 2.252 & 6.460 & 3.470 & 1.950 & 0.522 & 0.095 & 43.244 \\
\hline 2004 & 16 & 1.537 & 2.070 & 8.150 & 2.060 & 0.856 & 0.290 & 0.051 & 24.599 \\
\hline 2005 & 10 & 2.651 & 2.989 & 10.200 & 3.510 & 2.270 & 0.592 & 0.003 & 26.514 \\
\hline 2006 & 15 & 6.687 & 13.30489 & 52.900 & 8.370 & 2.430 & 0.258 & 0.007 & 100.306 \\
\hline 2007 & 23 & 8.792 & 19.25837 & 91.700 & 8.160 & 2.280 & 0.414 & 0.025 & 202.210 \\
\hline 2008 & 45 & 3.687 & 5.908 & 30.600 & 3.870 & 1.120 & 0.045 & 0.0002 & 165.901 \\
\hline 2009 & 33 & 3.642 & 5.034 & 24.600 & 3.750 & 1.450 & 0.923 & 0.004 & 120.191 \\
\hline Total & 207 & 3.794 & 8.412 & 91.700 & 3.610 & 1.450 & 0.379 & 0.0002 & 794.773 \\
\hline \multicolumn{10}{|c|}{ Panel B: Fraction of repurchased outstanding shares $(\%)$} \\
\hline 1999 & 6 & 2.621 & 2.202 & 6.001 & 4.189 & 2.059 & 0.884 & 0.536 & - \\
\hline 2000 & 13 & 3.780 & 4.133 & 14.990 & 5.042 & 2.869 & 0.875 & 0.206 & - \\
\hline 2001 & 13 & 4.449 & 3.863 & 13.434 & 4.525 & 3.742 & 1.950 & 0.410 & - \\
\hline 2002 & 15 & 2.364 & 2.800 & 9.343 & 3.463 & 1.164 & 0.391 & 0.025 & - \\
\hline 2003 & 18 & 4.615 & 4.090 & 14.121 & 6.021 & 3.088 & 1.374 & 0.500 & - \\
\hline 2004 & 16 & 3.916 & 4.494 & 14.981 & 5.958 & 2.209 & 0.766 & 0.140 & - \\
\hline 2005 & 10 & 4.680 & 4.869 & 17.448 & 5.465 & 3.464 & 1.752 & 0.013 & - \\
\hline 2006 & 15 & 8.207 & 9.967 & 36.777 & 11.290 & 6.141 & 0.342 & 0.033 & - \\
\hline 2007 & 23 & 5.159 & 5.019 & 23.130 & 7.885 & 4.236 & 1.216 & 0.020 & - \\
\hline 2008 & 45 & 3.675 & 3.673 & 12.139 & 5.661 & 2.777 & 0.165 & 0.007 & - \\
\hline 2009 & 33 & 5.849 & 5.762 & 26.971 & 6.891 & 4.411 & 2.063 & 0.069 & - \\
\hline Total & 207 & 4.525 & 5.041 & 36.777 & 6.001 & 3.182 & 0.888 & 0.007 & - \\
\hline
\end{tabular}

Notes: Panel A describes the repurchase value (in $\mathrm{f}$ million), which is calculated by collected repurchase share price multiplied by repurchase number of shares for each transaction and aggregated for each repurchase fund-year. Panel B displays the repurchase fraction for each financial year of the sample period, and it is the ratio of repurchase number of shares for each fund-year to the number of outstanding shares at the end of the fiscal year prior to the repurchases.

SD, standard deviation.

\section{Analysis of repurchase determinants using the fund-year approach}

Next I used the fund-year approach outlined in the 'Data and methodology' section to test the repurchase motivations. Descriptive statistics of the independent variables used in the fund-year analysis are presented in Table 5.

All variables were measured at the prior fiscal year-end. The mean of the discount variable shows that, on average, these funds traded at a discount to the NAV of $17.96 \%$ at the prior financial year-end. The maximum discount was $93.98 \%$, which was for the Benfield and Rea Investment Trust in the year 2000 . The average NAV return was $-0.23 \%$, the maximum was $1.71 \%$ and the minimum was $-5.57 \%$. The two alternative liquidity proxies of relative bid-ask spread and trading volume had average values of $9.97 \%$ and $0.11 \%$, respectively. The average price return was $-0.03 \%$.

The average of total assets across the fund-years was $£ 116.38 \mathrm{~m}$, with a maximum of $£ 3453.64 \mathrm{~m}$ for the Benfield and Rea Investment Trust at the end of 2007. The variable Lnasset has a skewness value close to 0 and kurtosis close to 3 , indicating that its distribution was almost normal. The average cash ratio was $5.32 \%$ and the average cash flow ratio was $-0.25 \%$. The average debt-to-asset ratio was $12.39 \%$ and the average payout ratio was $50.25 \%$.
In Table 5, I also compare the means and medians of the 207 repurchase fund-years with those of the 504 non-repurchase fund-years and show the results of the univariate analyses for each variable. I first conducted both the KolmogorovSmirnov test and the Shapiro-Wilk test for normality on all the variables and found that only Lnasset and Payout were normally distributed. Based on this, I performed a univariate test for normally distributed variables using aparametric $t$-test (two-sided $t$-test for difference in means of repurchase and non-repurchase subsamples) and performed a univariate test for non-normally distributed variables using a nonparametric Wilcoxon Z-test (test for difference in medians of repurchase and non-repurchase subsamples). I found median discounts at the end of the previous financial year to be significantly larger for those fund-years with repurchases (i.e. for 'repurchasers') than for those without ('nonrepurchasers'). Therefore, a desire to reduce the discount may be a motive for closed-end funds to repurchase shares. Repurchasers' median NAV returns at the end of the previous year were significantly smaller than those of the nonrepurchasers, indicating that closed-end funds may use repurchases to increase their NAV. However, repurchasers had significantly smaller (larger) median bid-ask spreads (trading volumes) than non-repurchasers, implying that the stocks of repurchasers are more liquid than those of nonrepurchasers. Contrary to the prediction, closed-end funds 
TABLE 5: Descriptive statistics and univariate test for repurchase and non-repurchase fund-years.

\begin{tabular}{|c|c|c|c|c|c|c|c|c|c|c|c|c|c|c|}
\hline \multirow[t]{2}{*}{ Variable } & \multicolumn{7}{|c|}{$\begin{array}{l}\text { Full sample } \\
(n=711)\end{array}$} & \multirow{2}{*}{$\begin{array}{l}\text { Normal } \\
\text { Distribution }(\mathrm{Y}) \\
\text { or not }(\mathrm{N})\end{array}$} & \multicolumn{2}{|c|}{$\begin{array}{l}\text { Repurchasers } \\
\quad(n=207)\end{array}$} & \multicolumn{2}{|c|}{$\begin{array}{l}\text { Non-repurchasers } \\
\quad(n=504)\end{array}$} & \multicolumn{2}{|c|}{$\begin{array}{l}\text { P-values for } \\
\text { difference in }\end{array}$} \\
\hline & Mean & Median & SD & Min & Max & Skewness & Kurtosis & & Mean & Median & Mean & Median & Means & Medians \\
\hline Discount (\%) & 17,96 & 13,21 & 22,18 & $-29,34$ & 93,98 & 1,73 & 7,08 & $\mathrm{~N}$ & 18,11 & 15,57 & 17,54 & 10,51 & - & 0,01 \\
\hline NAV return (\%) & $-0,23$ & $-0,04$ & 3,82 & $-5,57$ & 1,71 & $-25,75$ & 672,47 & $\mathrm{~N}$ & $-0,30$ & $-0,06$ & $-0,03$ & 0,00 & - & 0,01 \\
\hline Spread (\%) & 9,97 & 3,04 & 19,72 & 0,00 & 200,00 & 5,25 & 41,71 & $\mathrm{~N}$ & 4,89 & 2,21 & 11,86 & 3,50 & - & 0,00 \\
\hline Volume (\%) & 0,11 & 0,05 & 0,20 & 0,00 & 2,63 & 6,72 & 71,70 & $\mathrm{~N}$ & 0,13 & 0,07 & 0,10 & 0,04 & - & 0,00 \\
\hline Price return $(\%)$ & $-0,03$ & 0,00 & 0,43 & $-2,20$ & 2,25 & $-0,35$ & 7,49 & $\mathrm{~N}$ & $-0,02$ & 0,01 & $-0,04$ & 0,00 & - & 0,52 \\
\hline Asset ( $f$ million) & 116,38 & 49,86 & 286,76 & 1,99 & 3453,64 & 7,95 & 79,81 & $\mathrm{~N}$ & 109,91 & 39,93 & 133,74 & 66,76 & - & 0,00 \\
\hline Lnasset & 17,53 & 17,72 & 1,51 & 14,50 & 21,96 & $-0,23$ & 2,72 & Y & 17,34 & 17,50 & 18,01 & 18,02 & 0,00 & \\
\hline Cash (\%) & 5,32 & 2,54 & 8,07 & 0,00 & 100,00 & 4,91 & 44,28 & $\mathrm{~N}$ & 4,58 & 2,92 & 5,60 & 2,46 & - & 0,94 \\
\hline Cashflow (\%) & $-0,25$ & $-0,11$ & 5,32 & $-52,24$ & 33,72 & $-2,87$ & 45,55 & $\mathrm{~N}$ & $-0,07$ & 0,07 & $-0,32$ & $-0,21$ & - & 0,42 \\
\hline Leverage (\%) & 12,39 & 8,75 & 13,53 & 0,00 & 67,07 & 1,30 & 4,94 & $\mathrm{~N}$ & 7,22 & 4,54 & 14,33 & 11,44 & - & 0,00 \\
\hline
\end{tabular}

Notes: The final 711 fund-year observations include 207 repurchasers and 504 non-repurchasers. This table provides descriptive statistics for full sample and tests normality of each variable by both Kolmogorov-Smirnov test and Shapiro-Wilk test. If the tests are significant, then the data are normal, and vice versa. The results show that only Inasset and payout were normally distributed. Based on this, I make univariate test for normally distributed variables by parametric $t$-test (two-sided $t$-test for difference in means of repurchase and non-repurchase samples) and make univariate test for non-normally distributed variables by non-parametric Wilcoxon Z-test (test for difference in medians of these two subsamples). All variables are measured at prior fiscal year-end. Sprat and volume are alternative proxies for fund-year liquidity. Asset is the total asset value at prior fiscal year-end. All variables are defined in Table 3 . NAV return and price return were standardised.

seemed to take advantage of this liquidity to make share repurchases rather than aiming to increase liquidity through them.

The median price returns for the repurchase sample were insignificantly larger than those for the non-repurchase sample, which is contrary to the prediction that price return has a negative effect on fund repurchases and to the findings of Ikenberry and Vermaelen (1996) and Stephens and Weisbach (1998). Consistent with the expectation that a smaller fund is more likely to make repurchases, the fund size for the repurchase sample was significantly smaller than for the nonrepurchase sample. As predicted, the free cash flow theory on repurchases by conventional firms seems not to apply to closedend funds. Instead, the repurchasers even had a significantly smaller average cash ratio than the non-repurchasers at the prior fiscal year-end. I infer that repurchasers wished to boost their leverage ratios, because they had significantly lower median leverage ratios than the non-repurchasers at the end of the previous financial year. The results relating to dividend payouts were insignificant.

Next, I estimated the Tobit and Logit models, as outlined in the 'Methodology' section, to jointly test the predictions. Table 6 presents the results for 711 fund-years between the financial years 1999 and 2009. I applied each of the models (Tobit and Logit) first using the relative bid-ask spread and then using trading volume as alternative proxies for liquidity, resulting in four regressions in total. I report both the coefficients and the marginal effects for all of them.

The results for most of the continuous variables were consistent with those for the univariate tests. Specifically, Discount had a positive effect at the $1 \%$ significant level on both the repurchase fraction and the repurchase probability in all four regressions, indicating that funds with larger discounts are more likely to repurchase shares. This supports the prediction and both the agency effect and takeover avoidance theories discussed in the 'Introduction' section. It also confirms the fund directors' declaration that they use repurchases to reduce the level of the fund discount. The negative effect of NAV return was consistently significant at the $1 \%$ level in all models. This supports the expectation that funds repurchase shares to increase the NAV by realising the arbitrage profit from repurchase transactions, which is also stated as a motive for repurchasing in almost $30 \%$ of the sample of declared motivations (see Table 1). The coefficients of both spread and volume, however, had opposite signs to those I predicted, and in the Tobit model volume was even shown to have a significantly positive effect. This suggests that the declared objective of increasing liquidity is not in fact a motive behind funds' share repurchases.

The insignificant coefficients of price return rejected the relevant prediction, with no negative effect of price return on closed-end funds' repurchases. The fund size proxy (Lnasset) shows a negative and significant effect on both the repurchase percentage and the repurchase probability, which is contrary to the positive effect of firm size on a conventional firm's repurchases, as shown by Weisbenner (2000) and Fenn and Liang (2001). The insignificant coefficients of the cash, cash flow and payout ratios in the four models imply that, compelled by the special regulations and minimum dividend policy, closed-end funds domiciled in the UK repurchase shares neither to distribute excess capital nor as a substitute for dividend payouts. These findings confirm the corresponding hypotheses but differ from the findings in the existing literature relating to conventional firms, such as those by Jensen (1986), Stephens and Weisbach (1998), Jolls (1998), Dittmar (2000) and Fenn and Liang (2001). Despite this, the negative effect of the leverage ratio on both the repurchase percentage and probability for a closed-end fund is consistently significant at the $1 \%$ level. This means that a closed-end fund with a lower leverage ratio is more likely to repurchase shares, as predicted. This contradicts the findings of Lee et al. (2005).

As discussed in the 'Methodology' section, the coefficients of the Tobit and Logit models did not indicate the marginal effects of the independent variables. Therefore, I calculated the marginal effect for each variable to test its economic significance. Here, I focus on the interpretations of the continuous variables with significant coefficients. The marginal effect of the discount was $0.047 \%$ (or $0.044 \%$ ) on 
TABLE 6: Multivariate analysis for the decision of fund-year repurchase transactions.

\begin{tabular}{|c|c|c|c|c|c|c|c|c|c|}
\hline \multirow[t]{2}{*}{ Variables } & \multirow[t]{2}{*}{ sign } & \multicolumn{4}{|c|}{ Dependent variable: repurchase fraction (\%) } & \multicolumn{4}{|c|}{ Dependent variable: repurchase dummy } \\
\hline & & Coefficient & Marginal effect & Coefficient & Marginal effect & Coefficient & Marginal effect & Coefficient & Marginal effect \\
\hline Discount & $(+)$ & $0.188 * * *$ & 0.047 & $0.174 * * *$ & 0.044 & $0.128 * * *$ & 0.013 & $0.100 * * *$ & 0.013 \\
\hline NAV return & $(-)$ & $-0.350 * * *$ & -0.088 & $-0.170 * * *$ & -0.043 & $-0.586 * * *$ & -0.062 & $-0.654 * * *$ & -0.082 \\
\hline Spread & $(+)$ & -0.124 & -0.031 & - & - & -0.086 & -0.009 & - & - \\
\hline Volume & $(-)$ & - & - & $3.968 * *$ & 0.998 & - & - & 0.497 & 0.062 \\
\hline Price return & $(-)$ & 0.746 & 0.188 & 0.483 & 0.121 & -0.372 & -0.039 & -0.407 & -0.051 \\
\hline Lnasset & $(-)$ & $-0.523 * * *$ & -0.132 & $-0.856 * * *$ & -0.215 & $-0.153 * *$ & -0.016 & $-0.358 * * *$ & -0.045 \\
\hline Cash & (?) & 0.021 & 0.005 & -0.029 & -0.007 & 0.002 & 0.000 & 0.008 & 0.001 \\
\hline Cashflow & (?) & 0.046 & 0.012 & 0.038 & 0.010 & 0.016 & 0.002 & 0.016 & 0.002 \\
\hline Leverage & $(-)$ & $-0.233 * * *$ & -0.059 & $-0.255 * * *$ & -0.064 & $-0.062 * * *$ & -0.007 & $-0.077 * * *$ & -0.010 \\
\hline Payout & (?) & 0.001 & 0.000 & 0.001 & 0.000 & -0.001 & 0.000 & -0.001 & 0.000 \\
\hline Sector dummy & (?) & Yes & - & Yes & - & Yes & - & Yes & - \\
\hline Year dummy & (?) & Yes & - & Yes & - & Yes & - & Yes & - \\
\hline Constant & & -7.050 & - & $-13.052 * *$ & - & -3.355 & - & $-6.949 * *$ & - \\
\hline Pseudo R2 & & 0.121 & - & 0.121 & - & 0.344 & - & 0.325 & - \\
\hline
\end{tabular}

Notes: This table presents Tobit and Logit results for 711 fund-years from financial year 1999 to 2009. In this sample, there are 207 repurchasers and 504 non-repurchasers. The dependent variable for Tobit models is repurchase fraction which is repurchased number of shares in fiscal year $t$ divided by outstanding shares at the end of year $t-1$ and set to 0 for non-repurchase fund-years; in (\%). Dependent variable for Logit models is repurchase dummy which equals to 1 (or 0) if a fund did (or did not) repuchase in fiscal year t. Spread and trading volume are alternative proxies for liquidity. All independent variables are measured at prior fiscal year-end and are defined in Table 3.I report coefficients and marginal effects for each model. Expected signs are derived from liquidity. All independent variables are measured at prior fiscal

$*, * *$ and $* * *$ denote statistical significance at the $10 \%, 5 \%$ and $1 \%$ level, respectively.

the repurchase percentage and $0.013 \%$ on the repurchase probability. NAV return had a negative marginal effect of $-0.088 \%$ (or $-0.043 \%$ ) on the repurchase percentage and $-0.062 \%$ (or $-0.082 \%$ ) on the probability of repurchase. Trading volume in the second Tobit regression had a high and positive marginal effect on the repurchase percentage of $0.998 \%$. A $1 \%$ decrease in Lnasset would increase the repurchase percentage by $0.132 \%$ (or $0.215 \%$ ) and the repurchase probability by $0.016 \%$ (or $0.045 \%$ ). A $1 \%$ decrease in the leverage ratio at the end of the prior financial year would increase the repurchase percentage by $0.059 \%$ (or $0.064 \%$ ) and the repurchase probability by $0.007 \%$ (or $0.01 \%$ ).

Therefore, for the first Tobit regression, Lnasset had the greatest economic impact on the repurchase percentage, and the NAV return had the next largest effect. In the second Tobit regression, trading volume was the most prominent factor, with Lnasset next. In comparison, both of the Logit regressions showed that the repurchase probability was most sensitive to the NAV return and was also strongly sensitive to Lnasset.

\section{Conclusions}

This paper examines the determinants of the decision to carry out open-market repurchase transactions by conventional closed-end funds domiciled in the UK. Because many fund directors state their repurchase objectives in order to gain repurchase authorisation from their shareholders at annual general meetings, it is interesting to investigate whether the declared objectives really motivate the closed-end funds to buy back shares or whether they are just tools to alleviate pressure from shareholders. Also, based on the institutional characteristics and special regulations of UK closed-end funds, it is necessary to explore their unique set of repurchase motivations, which should be different from those of conventional firms. By simultaneously analysing all the possible motives for closed-end fund repurchases, this paper provides answers to these questions that have been unsolved and ignored in the existing literature.

I manually collected 3221 repurchase execution announcements for the 117 closed-end funds from their IPO dates through the end of 2009. Using the fund-year approach, I found that funds do in fact repurchase in order to reduce discounts and increase NAV per share but not to increase liquidity for the next financial year as they state. I also found that funds repurchase shares to increase leverage ratios. Unlike conventional firms, funds do not repurchase shares either to distribute excess cash or to replace dividend payouts. The size of a closed-end fund was found to negatively affect its repurchases on a financialyear basis.

The evidence proves that the special regulations and institutional intricacies of closed-end funds lead to unique motivations for their repurchases. It also confirms the plausibility of the agency theory, takeover avoidance theory and repurchase-profits theory for closed-end funds. Specifically, if the discounts widen, closed-end fund directors use the threat of repurchases (that is, the threat to cut off their management fees and reduce agency costs) against fund managers. They also repurchase their shares to defend buyouts by arbitrageurs who might reorganise the fund or vote out the management. The repurchase-profits of closedend funds can be realised through an increase in NAV per share for the remaining shareholders.

This study not only fills a gap in the academic literature but also provides policy implications for investors and regulators of the closed-end fund industry. Given the marked increase in recent years in the number of repurchase transactions by closed-end funds (as documented in this study; see Table 4), both shareholders and regulators need 
to be aware of funds' unique repurchase motives and take account of all the relevant fund characteristics before voting for a repurchase programme or revising regulatory restrictions on fund repurchases.

To make robustness checks to the fund-year approach, I also tested the motivations of the first repurchase transaction after the fund IPO. As shown in Appendix 1, the results were qualitatively the same. Specifically, a closed-end fund with a higher discount, a lower NAV return, a more liquid secondary market for its stock and a smaller fund size is more likely to make a repurchase transaction.

\section{Acknowledgements}

The author would like to express her sincere gratitude and appreciation to Susanne Espenlaub, Arif Khurshed, Andrew Stark, Martin Walker, Norman Strong and Michael J. Brennan from Manchester Business School, for their helpful comments and suggestions. The author would like to acknowledge her gratitude to the organisers and participants at the 23rd Australasian Banking and Finance Conference, European Financial Management Symposium on Alternative Investments and Financial Management Association European Conference, for the constructive feedback received. This work was supported by grants from the Beijing Municipal Commission of Education 'Pilot Reform of Accounting Discipline Clustering'.

\section{Competing interests}

The author declares that she has no financial or personal relationships which may have inappropriately influenced her in writing this article.

\section{References}

AIC, 2010,A handbook for directors of investment companies, The Association of Investment Companies, London, UK.

Akhigbe, A., Kim, D. \& Madura, J., 2007, 'Price performance following share-repurchase announcements by closed-end funds', Financial Review 42(4), 537-555. https:// doi.org/10.1111/j.1540-6288.2007.00182.x

Allen, F., Bernardo, A.E. \& Welch, I., 2000, 'A theory of dividends based on tax clienteles', The Journal of Finance 55(6), 2499-2536. https://doi.org/10.1111/ 0022-1082.00298

An, J., Gemmill, G. \& Thomas, D.C., 2012, 'The agency effect of repurchases on closed end funds', European Financial Management 18(2), 240-270. https://doi.org/ 10.1111/j.1468-036X.2009.00529.x

Barclay, M.J., Holderness, C.G. \& Pontiff, J., 1993, 'Private benefits from block ownership and discounts on closed-end funds', Journal of Financial Economic 33(3), 263-291. https://doi.org/10.1016/0304-405X(93)90008-Y

Barth, M.E. \& Kasznik, R., 1999, 'Share repurchases and intangible assets', Journal of Accounting and Economics 28(2), 211-241. https://doi.org/10.1016/S0165-4101 (99)00020-8

Bartov, E., 1991, 'Open-market stock repurchases as signals for earnings and risk changes', Journal of Accounting and Economics 14(3), 275-294. https://doi.org/ 10.1016/0165-4101(91)90015-G

Brav, A., Graham, J.R., Harvey, C.R. \& Michaely, R., 2005, 'Payout policy in the 21s century', Journal of Financial Economics 77(3), 483-527. https://doi.org/10.1016/j. jineco.2004.07.004

Comment, R. \& Jarrell, G.A., 1991, 'The relative signalling power of Dutch-auction and fixed-price self-tender offers and open-market share repurchases', The Journal of Finance 46(4), 1243-1271. https://doi.org/10.1111/j.1540-6261.1991. tb04617.x
Dimson, E. \& Minio-Paluello, C., 2002, The closed-end fund discount, The Research Foundation of the Association for Investment Management and Research (AIMR), New York.

Dittmar, A.K., 2000, 'Why do firms repurchase stock?', The Journal of Business 73(3), 331-355. https://doi.org/10.1086/209646

Fenn, G.W. \& Liang, N., 2001, 'Corporate payout policy and managerial stock incentives', Journal of Financial Economics 60(1), 45-72. https://doi.org/10.1016/S0304-405X (01)00039-3

Gemmill, G. \& Thomas, D.C., 2002, 'Noise trading, costly arbitrage, and asset prices: Evidence from closed-end funds', The Journal of Finance 57(6), 2571-2594. https:// doi.org/10.1111/1540-6261.00506

Gemmill, G. \& Thomas, D.C., 2006, 'The impact of corporate governance on closed end funds', European Financial Management 12(5), 725-749. https://doi.org/10.1111/ j.1468-036X.2006.00274.x

Grullon, G. \& Michaely, R., 2004, 'The information content of share repurchase programs', The Journal of Finance 59(2), 651-680. https://doi.org/10.1111/j.15406261.2004.00645.x

Hovakimian, A., Opler, T. \& Titman, S., 2001, 'The debt-equity choice', Journal of Financial and Quantitative Analysis 36(1), 1-24. https://doi.org/10.2307/2676195

Ikenberry, D. \& Vermaelen, T., 1996, 'The option to repurchase stock', Financial Management 25(4), 9-24. https://doi.org/10.2307/3665586

Jagannathan, M. \& Stephens, C., 2003, 'Motives for multiple open-market repurchase programs', Financial Management 32(2), 71-91. https://doi.org/10.2307/3666337

Jensen, M.C., 1986, 'Agency costs of free cash flow, corporate finance, and takeovers', The American Economic Review 76(2), 323-329.

Jolls, C., 1998, Stock repurchases and incentive compensation, SSRN eLibrary, Cambridge, MA.

Kahle, K.M., 2002, 'When a buyback isn't a buyback: Open market repurchases and employee options', Journal of Financial Economics 63(2), 235-261. https://doi. org/10.1016/S0304-405X(01)00095-2

Lee, C.H., Hsieh, C. \& Peng, X., 2005, 'Why do REITs engage in open-market repurchases?', Journal of Economics and Finance 29(3), 313-320. https://doi.org/ 10.1007/BF02761577

Lie, E., 2005, 'Operating performance following open market share repurchase announcements', Journal of Accounting and Economics 39(3), 411-436. https:// doi.org/10.1016/j.jacceco.2005.04.001

Liu, C.S. \& Ziebart, D.A., 1997, 'Stock returns and open-market stock repurchase announcements', Financial Review 32(4), 709-728. https://doi.org/10.1111/ j.1540-6288.1997.tb00907.x

Netter, J.M. \& Mitchell, M.L., 1989, 'Stock-repurchase announcements and insider transactions after the October 1987 stock market crash', Financial Management 18(3), 84-96. https://doi.org/10.2307/3665651

Nohel, T. \& Tarhan, V., 1998, 'Share repurchases and firm performance: New evidence on the agency costs of free cash flow', Journal of Financial Economics 49(2), 187-222.

Opler, T.C. \& Titman, S., 1994, The debt-equity choice: An analysis of issuing firms, SSRN eLibrary, New York.

Oswald, D. \& Young, S., 2004, 'What role taxes and regulation? A second look at open market share buyback activity in the UK', Journal of Business Finance \& Accounting 31(1-2), 257-292. https://doi.org/10.1111/j.0306-686X.2004.0007.x

Oswald, D. \& Young, S., 2008, 'Share reacquisitions, surplus cash, and agency problems', Journal of Banking \& Finance 32(5), 795-806. https://doi.org/10.1016/ j.jbankfin.2007.05.010

Padgett, C. \& Wang, Z., 2007, UK share repurchase activity: The effects of free cash flow and signalling, SSRN eLibrary, Reading.

Pontiff, J., 1995, 'Closed-end fund premia and returns implications for financial marke equilibrium', Journal of Financial Economics 37(3), 341-370. https://doi.org/ 10.1016/0304-405X(94)00800-G

Porter, G.E., Roenfeldt, R.L. \& Sicherman, N.W., 1999, 'The value of open market repurchases of closed-end fund shares', The Journal of Business 72(2), 257-276. https://doi.org/10.1086/209613

Rau, P.Â.R. \& Vermaelen, T., 2002, 'Regulation, taxes, and share repurchases in the United Kingdom', The Journal of Business 75(2), 245-282. https://doi.org/10.1086/ 338703

Singh, A.K., Zaman, M.A. \& Krishnamurti, C., 1994, 'Liquidity changes associated with open market repurchases', Financial Management 23(1), 47-55. https://doi.org/ 10.2307/3666055

Stephens, C.P. \& Weisbach, M.S., 1998, 'Actual share reacquisitions in open-market repurchase programs', The Journal of Finance 53(1), 313-333. https://doi. org/10.1111/0022-1082.115194

Vermaelen, T., 1981, 'Common stock repurchases and market signalling: An empirical study', Journal of Financial Economics 9(2), 139-183. https://doi.org/10.1016/ 0304-405X(81)90011-8

Wang, C.S., Strong, N., Tung, S. \& Lin, S., 2009, 'Share repurchases, the clustering problem, and the free cash flow hypothesis', Financial Management 38(3), 487-505. https:// doi.org/10.1111/j.1755-053X.2009.01045.X

Weisbenner, S.J., 2000, Corporate share repurchases in the 1990s: What role do stock options play? SSRN eLibrary, New York. 


\section{Appendix 1}

TABLE A1: Multivariate analysis for the first repurchase decision.

This table presents logit results for the 427 fund-date observations. In this sample, there are 76 first repurchasers and randomly selected 351 nonrepurchasers from 23 September 1998 to 16 December 2009. Discount, NAVreturn, Spread, Pricereturn and Marketcap are market variables using data on the trading day prior to the first repurchase and non-repurchase dates. Cash, Cashflow, Leverage and Payout are accounting variables using data at the fiscal year-end prior to the first repurchase and non-repurchase dates. All variables are defined in Table 3 Panel B. Here I only report coefficients and marginal effects for the model with the best fitness or highest Pseudo R2. *,** and *** denote statistical significance at the $10 \%, 5 \%$ and $1 \%$ level 'respectively. Expected signs are derived from hypotheses.

\begin{tabular}{lccc}
\hline $\begin{array}{l}\text { Independent } \\
\text { variables }\end{array}$ & Expected sign & \multicolumn{1}{c}{$\begin{array}{c}\text { Dependent Variable: } \\
\text { First repurchase(1) and Non-repurchase(0) }\end{array}$} \\
\hline Discount & $(+)$ & $0.018^{* *}$ & 0.002 \\
NAV Return & $(-)$ & $-0.058^{* *}$ & -0.006 \\
Spread & $(+)$ & $-0.042^{* *}$ & -0.004 \\
Price Return & $(-)$ & 0.029 & 0.003 \\
Marketcap & $(-)$ & $-0.004^{* *}$ & 0.000 \\
Cash & $(?)$ & 0.021 & 0.002 \\
Cashflow & $(?)$ & 0.034 & 0.003 \\
Leverage & $(-)$ & -0.007 & -0.001 \\
Payout & $(?)$ & -0.003 & 0.000 \\
Sector Dummy & $(?)$ & YES & YES \\
Year Dummy & $(?)$ & YES & YES \\
Constant & & -2.713 & - \\
No. Observation & & 427 & - \\
Pseudo R2 & & 0.131 & - \\
\hline
\end{tabular}

